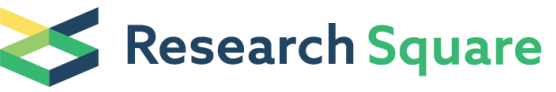 \\ Preprints are preliminary reports that have not undergone peer review. \\ They should not be considered conclusive, used to inform clinical practice, or referenced by the media as validated information.
}

\section{Pan-Genome Analysis Reveals The Molecular Targets of Identification and Virulence Detection in Mucoralean Fungi}

\section{Meijie Zhang}

Chinese Academy of Medical Sciences and Peking Union Medical College Hospital and Institute of Dermatology: Affiliated Hospital for Skin Diseases of Chinese Academy of Medical Sciences

\section{Wenqi Xu}

Chinese Academy of Medical Sciences and Peking Union Medical College Hospital and Institute of Dermatology: Affiliated Hospital for Skin Diseases of Chinese Academy of Medical Sciences

\section{Huan Mei}

Chinese Academy of Medical Sciences and Peking Union Medical College Hospital and Institute of Dermatology: Affiliated Hospital for Skin Diseases of Chinese Academy of Medical Sciences

\section{Naicen Ge}

Chinese Academy of Medical Sciences and Peking Union Medical College Hospital and Institute of Dermatology: Affiliated Hospital for Skin Diseases of Chinese Academy of Medical Sciences

\section{Ge Song}

Chinese Academy of Medical Sciences and Peking Union Medical College Hospital and Institute of Dermatology: Affiliated Hospital for Skin Diseases of Chinese Academy of Medical Sciences

\section{Ye Tao}

shanghai biozeron biotechnology Co Ltd

\section{Weida Liu}

Chinese Academy of Medical Sciences Institute of Dermatology: Affiliated Hospital for Skin Diseases of Chinese Academy of Medical Sciences

\section{Guanzhao Liang ( $\nabla$ guanzhaoguan@126.com )}

Chinese Academy of Medical Sciences and Peking Union Medical College Hospital and Institute of Dermatology: Affiliated Hospital for Skin Diseases of Chinese Academy of Medical Sciences

\section{Research}

Keywords: Mucorales, epidemiology, molecular targets, fungal virulence

Posted Date: February 28th, 2022

DOI: https://doi.org/10.21203/rs.3.rs-1346045/v1 
License: (c) (i) This work is licensed under a Creative Commons Attribution 4.0 International License. Read Full License 


\section{Abstract}

Mucoralean fungi offer various pathogens to cause mucormycosis, especially in immunodeficient patients. Over the past decades, both the morbidity and mortality of mucormycosis have increased rapidly, particularly in developing countries. Nowadays, mucormycosis more often happens in India for the COVID-19 pandemic and its backward diagnostic techniques. Our epidemiologic outcomes show several identifications of Mucoralean fungi are limited to genus, while Rhizopus species, Mucorspecies and Lichtheimia species have high proportions. To find more molecular targets to make rapid and accurate identifications of Mucorales genus and species, Pan-genome analysis and Phylogenetic tree are conducted with four Mucorales isolates we sequenced and 43 fungi from NCBI. A few Mucorales-specific genes have been found such as STE/STE20 protein kinase, GH36 and sel1 repeat protein. Mucorales genus-specific genes are also found in Lichtheimia species and Cunninghamella species, which covered cellular structure, biochemistry metabolism, molecular processing, and signal transduction. Reported proteins related to the virulence of Mucorales species were run with Orthofinder and 112092, cotH3, gcn4 and igp 1 have shown the potential to be the direct identification as well as the virulence detection of Mucorales species. The molecular biological techniques need to be promoted, for which our study provide hypothesis and feasibility analysis.

\section{Introduction}

Mucorales can cause mucormycosis in human beings, of which different genus and species often lead to distinct characteristics of infections. As a well-known life-threatening disease, mucormycosis especially occurs in individuals with immunodeficiency [1], diabetes mellitus [2] or major trauma [3]. A review of global epidemiology of mucormycosis had analyzed 851 cases from January 2000 to January 2017 in diverse aspects [4], illustrating a detailed spectrum of causative pathogens. As a result, Rhizopus arrhizus (70/447) accounted for the largest proportion, followed by Lichtheimia corymbifera (41/447). The review had also pointed out that the disease burden in Europe was higher than that in Asia, which was inconsistent with other studies reporting the incidence of mucormycosis rising much higher in India and China with uncontrolled diabetes mellitus [2,5-7]. To correct the incidence data error, a recent review studied population-based prevalence reported from various countries, and found the incidence was far underestimated in India and other Asian countries for under-reporting during that period [8].

Since Coronavirus Disease 2019 (COVID-19) burst, multiple case reports have been described co-infected with mucormycosis, most of which are from India, especially in diabetic patients and those overusing corticosteroids, leading to the higher fatality and the worse pandemic outcome [9]. As mentioned in one earlier retrospective analysis of SARS and influenza data from worldwide, Mucorales should been called for high attention in this COVID-19 pandemic [10]. While the mucormycosis is more common in developing countries, their laboratory facility is sub-optimal for identification to Mucorales genus and species which delays the precise treatment. Despite of available diagnostic technologies proposed as direct or fluorescent microscopy and culture of specimens for morphological identification or DNA 
sequencing, promising DNA targets are needed to detect fungi directly in serum and other available body fluids.

Considering the rising attention of proteins associated to Mucorales virulence, several DNA targets have been demonstrated potential to detect mucormycosis and to generate novel antifungals against Mucorales. Genes regulating the virulence-specific response were mainly revealed through the transcriptomic response of Mucor circinelloides (M. circinelloides) and validated in vivo [11], including atf1 (activating transcription factor 1), atf2 (activating transcription factor 2), gcn4 (general control nonderepressible 4), aqp 1 (aquaporin 1), ico 1 (isochorismatase 1), igp 1 (immunoglobulin-like protein) and pps 1 (signal peptide-containing proteins), performing important roles in Mucorales survival following phagocytosis, germination inside the phagosome, or the virulence in mice. Besides, the genes $m c p / D(M$. circinelloides Phospholipase D like protein) and mcmyo5 (the gene encoding M. circinelloides Myosin 5) have been found to maintain full virulence of $M$. circinelloides and validated both in Galleria mellonella and mice [12], and the deletion of gene 112092 which codes for a hypothetical extracellular protein of unknown function can result in significant reduction of virulence [13]. To the contrary, deletion of arf1 (ADP-ribosylation factor) in M. circinelloides has been reported increasing the strain virulence [14], arl1 (arf-like proteins) can influence mycelial growth in distinct transcriptional expression patterns [15]. Nagy et al found that the disruption of $h m g R$ (3-hydroxy-3-methylglutaryl coenzyme A reductase) genes seem to affect $M$. circinelloides in germination of spores and adaptation to the oxidative stress [16]. As the inhibitors of $h m g R$, statins had been reported that they can decrease the virulence of Rhizopus arrhizus [17].

Ibrahim et al have published a series of researches about the frequent pathogenic Mucorales fungi Rhizopus arrhizus. They proposed cotH3 (the spore coat protein homolog) cell surface proteins [18], the fungal ligands that mediate attachment to GRP78 during host cell invasion, as well as fob (the ferrioxamine binding) cell surface proteins [19], the fungal receptors that mediate attachment to ferrioxamine, show requirements in full virulence of Rhizopus arrhizus in vivo. In the current study, we sought to identify the Mucorales-specific genes and their respective roles in the diverse pathogenesis of mucormycosis through whole genome sequence, pan-genome analysis and orthofinder.

\section{Materials And Methods}

\subsection{Search strategies and data analysis}

A systematic search comprising keywords and MeSH (Details can be seen in supplementary material Appendix S1.) for causative pathogens was carried out in PUBMED database. Searches were limited to studies involving humans, published in English from 2017 to 2021, of which the final search performed in July 2021. For exclusion, the published cases were removed with conditions of: (i) irrelevant titles or abstracts, (ii) full text unavailable, (iii) non-English articles, (iv) editorial or review, (v) pool identification, (vi) wrong fungi taxonomy. 


\subsection{Fungi isolates collection and DNA sequencing library construction}

Clinical isolates Mucor irregularis (B50a), Lichtheimia corymbifera (B63a), Mucor hiemalis (B66h) and Rhizopus arrhizus (B81a) were maintained at the CAMS Collection Center of Pathogen Microorganisms-D (CAMS-CCPM-D; Nanjing, China) and collected from MEA (Malt Extract Agar) media after a 4-day culture at $28^{\circ} \mathrm{C}$. Genomic DNA, at least $1 \mu \mathrm{g}$, was used for sequencing library construction. Paired-end libraries with insert sizes of $\sim 400 \mathrm{bp}$ were prepared following Illumina's standard genomic DNA library preparation procedure. Purified genomic DNA was sheared into smaller fragments with a desired size by Covaris, and blunt ends were generated by using T4 DNA polymerase. The 3' end of the blunt phosphorylated DNA fragments was added with an 'A' base, then adapters were ligated to the ends of the DNA fragments. Through gel-electrophoresis, the desired fragments can be purified, selectively enriched, and amplified by PCR. The index tag could be introduced into the adapter at the PCR stage as appropriate. After a library quality test, the qualified Illumina pair-end library would be used for Illumina NovaSeq 6000 sequencing (150bp*2, Shanghai BIOZERON Co., Ltd.).

Strains genomic DNA was initially extracted using Invitrogen PureLink® Genomic DNA kit and tested by the NanoDrop ND-1000 Spectrophotometer (Thermo Fisher Scientific) for its quantity and quality. Purified further using the Quick-DNA Miniprep Plus kit, the whole genome sequencing was performed by Pacific Biosciences Sequel II technology (PacBio). Then the DNA SMRTbell libraries were made using the Express Template Prep Kit 2.0 from PacBio according to the manufacturer's protocol. Samples were pooled into a single multiplexed library and size was selected using Sage Sciences' BluePippin with the $0.75 \%$ DF Marker S1 High-Pass 6 - 10 kb v3 run protocol and S1 marker. Another size selection cut-off of 8000 (BPstart value) was used. After size selection, SMRTbell library was annealed and bound according to the SMRT Link Set Up and sequenced on a Sequel II. Raw PacBio reads were converted to fasta format with Samtools Fasta (http://www.htslib.org/doc/samtools.html).

\subsection{Genome assembly and annotation}

The raw paired end reads were trimmed, and quality-controlled by Trimmomatic with parameters (SLIDINGWINDOW: 4:15 MINLEN:75) (version 0.36

http://www.usadellab.org/cms/uploads/supplementary/Trimmomatic). Clean data obtained by above quality control processes was used to do further analysis.

The B50a, B63a, B66h and B81a genomes were sequenced using a combination of PacBio RS and Illumina sequencing platforms. The lllumina data was used to evaluate the complexity of the genome and correct the PacBio long reads. Firstly, we used ABySS

(http://www.bcgsc.ca/platform/bioinfo/software/abyss) to do genome assembly with multiple-Kmer parameters and to get the optimal results of the assembly. Secondly canu (https://github.com/marbl/canu) was used to assemble the PacBio corrected long reads. Finally, GapCloser software was subsequently applied to fill up the remaining local inner gaps and correct the 
single base polymorphism (https://sourceforge.net/projects/soapdenovo2/files/GapCloser/) for the final assembly results.

We used Repeatmasker (http://www.repeatmasker.org/) by default parameters to identify Genome repeat information. The ab initio prediction method was used to get gene models for strain B50a, B63a, B66h and B81a. Gene models were identified using Augustus (http://bioinf.uni-

greifswald.de/augustus/binaries/). Then all gene models were blast against non-redundant (NR in NCBI) database, SwissProt (http://uniprot.org), KEGG (http://www.genome.jp/kegg/), and COG (http://www.ncbi.nlm.nih.gov/COG) to do functional annotation by blastp module. In addition, tRNAs were identified using the tRNAscan-SE (v1.23, http://lowelab.ucsc.edu/tRNAscan-SE) and rRNA were determined with the RNAmmer (v1.2, http://www.cbs.dtu.dk/services/RNAmmer/).

\subsection{Pan-genome analysis and phylogenetic tree creation}

Despite of the genomes of the four clinical isolates, we obtained genomic data of 43 more fungi from the National Center for Biotechnology Information's (NCBI) GenBank facility, including 25 species of Mucorales and other 22 pathogenic non-Mucorales species (Table S1). Core pan-genome analysis and evolutionary tree construction were carried out with the Orthofinder software (version 2.3.11) with default parameters. The information of Mucorales-specific and genus-specific orthogroups were extracted by Python script.

\subsection{Virulence factors analysis}

We have also selected proteins related to the virulence of Mucorales, referring to the published literature, and used blast v2.2.31 against the sequence of the 47 strains we included in total (Table 1). In this analysis, blast results were considered significant when the E-value was $<1 e-5$, which is a generally accepted consensus cut-off. The best query results selected were combined with orthogroup gene assemblies to construct specific orthogroups related to virulence. 
Table 1

Information of the genes related to the virulence of Mucorales from published literature.

\begin{tabular}{|c|c|c|c|c|c|c|}
\hline Name & Gene & GenelD & Platform & Description & Validated strains & Ref \\
\hline \multirow[t]{2}{*}{ atf } & atf1 & 190180 & JGP & $\begin{array}{l}\text { activating } \\
\text { transcription factor } 1\end{array}$ & $\begin{array}{l}\text { Mucor } \\
\text { circinelloides }\end{array}$ & 6 \\
\hline & atf2 & 156289 & JGP & $\begin{array}{l}\text { activating } \\
\text { transcription factor } 2\end{array}$ & Unknown & \\
\hline gcn4 & gcn4 & 85517 & JGP & $\begin{array}{l}\text { general control } \\
\text { nonderepressible } 4\end{array}$ & Unknown & \\
\hline aqp1 & aqp 1 & 167023 & JGP & aquaporin 1 & Unknown & \\
\hline ico1 & $i c o 1$ & 155573 & JGP & isochorismatase 1 & Unknown & \\
\hline igp 1 & igp1 & 154866 & JGP & $\begin{array}{l}\text { immunoglobulinlike } \\
\text { protein }\end{array}$ & Unknown & \\
\hline pps1 & pps1 & 115037 & JGP & $\begin{array}{l}\text { signal peptide- } \\
\text { containing protein }\end{array}$ & Unknown & \\
\hline \multirow[t]{3}{*}{ arf } & arf1 & 157293 & JGP & $\begin{array}{l}\text { ADP-ribosylation } \\
\text { factor }\end{array}$ & $\begin{array}{l}\text { Mucor } \\
\text { circinelloides }\end{array}$ & 1 \\
\hline & $\operatorname{arl1}$ & 155647 & JGP & Arf-like proteins & Unknown & \\
\hline & arl2 & 112008 & JGP & Arf-like proteins & Unknown & \\
\hline momyo5 & memyo5 & 51513 & JGP & $\begin{array}{l}\text { Myosin class V } \\
\text { protein }\end{array}$ & $\begin{array}{l}\text { Mucor } \\
\text { circinelloides }\end{array}$ & 5 \\
\hline$m c p / D$ & $m c p / D$ & 134906 & JGP & $\begin{array}{l}\text { Phospholipase D like } \\
\text { protein }\end{array}$ & Unknown & \\
\hline 112092 & 112092 & 112092 & JGP & hypothetical protein & $\begin{array}{l}\text { Mucor } \\
\text { circinelloides }\end{array}$ & 12 \\
\hline \multirow[t]{3}{*}{$h m g R$} & $h m g R 1$ & KJ508882 & $\mathrm{NCBI}$ & $\begin{array}{l}\text { HMG-CoA reductase } \\
1 \text { gene, partial cds }\end{array}$ & \multirow{3}{*}{$\begin{array}{l}\text { Mucor } \\
\text { circinelloides } f \text {. } \\
\text { lusitanicus, } \\
\text { Aspergillus } \\
\text { fumigatus, } \\
\text { Candida albicans } \\
\text { or Fusarium } \\
\text { graminearum }\end{array}$} & 2 \\
\hline & $h m g R 2$ & KJ508884.1 & $\mathrm{NCBI}$ & $\begin{array}{l}\text { HMG-CoA reductase } \\
2 \text { gene, partial cds }\end{array}$ & & \\
\hline & $h m g R 3$ & KJ508883.1 & $\mathrm{NCBI}$ & $\begin{array}{l}\text { HMG-CoA reductase } \\
3 \text { gene, partial cds }\end{array}$ & & \\
\hline cotH3 & $\operatorname{cotH3}$ & EIE87171.1 & $\mathrm{NCBI}$ & $\begin{array}{l}\text { spore coat protein } \\
\text { homologs } \\
\text { RO3G_11882 }\end{array}$ & $\begin{array}{l}\text { Rhizopus } \\
\text { delemar RA 99- } \\
880\end{array}$ & 9 \\
\hline
\end{tabular}

JGP: Joint Genome Institute Mucor circinelloides v2.0 (http://genome.jgi.doe.gov/vista_embed/? organism $=$ Mucci2) 


\begin{tabular}{|lllllll|}
\hline Name & Gene & GenelD & Platform & Description & Validated strains & Ref \\
\hline fob & fob2 & EIE86289.1 & NCBI & $\begin{array}{l}\text { ferrioxamine binding } \\
\text { cell surface protein } \\
\text { RO3G_11000 }\end{array}$ & $\begin{array}{l}\text { Rhizopus } \\
\text { delemarRA 99- } \\
880\end{array}$ & 11 \\
fob1 & EIE80382.1 & NCBI & $\begin{array}{l}\text { ferrioxamine binding } \\
\text { cell surface } \\
\text { proteinsRO3G_05087 }\end{array}$ & $\begin{array}{l}\text { Rhizopus } \\
\text { delemar RA 99- } \\
880\end{array}$ \\
\hline \multicolumn{7}{|l|}{$\begin{array}{l}\text { JGP: Joint Genome Institute Mucor circinelloides v2.0 (http://genome.jgi.doe.gov/vista_embed/? } \\
\text { organism = Mucci2) }\end{array}$} \\
\hline
\end{tabular}

NCBI: National Center for Biotechnology information (https://www.ncbi.nlm.nih.gov/protein)

\section{Results}

\subsection{Causative pathogens of mucormycosis}

The initial database searching results covered 672 articles with 25 duplications, which had been deleted with exclusions (Figure 1). 631 new patient datas from 272 eligible articles were included in the final analysis (Appendix S2). Merged with the data from 2000 to 2017 without duplications [4], 1078 individual cases all together have been analyzed.

A total of eight major genera (36 specific species and several unidentified species) of Mucorales organisms were identified in 1078 mucormycosis patients (Figure 2). Frequency outcomes showed that Rhizopus spp. (616/1078, 57.14\%) was the most common pathogenic species, followed by Mucorspp. (124/1078, 11.5\%) and Lichtheimia spp. (105/1078, 9.74\%). So far, Rhizopus arrhizus (239/403, 59.31\%) and Lichtheimia corymbifera $(23 / 45,51.11 \%)$ was the most frequent strain in Rhizopus spp. and Lichtheimia spp. respectively. Majority of Mucor spp. had not been identified to species level (48/61, 78.69\%), which might be partially accounted for the countries with high incidence of mucormycosis lacking in adequate laboratory technologies for their poor sanitation and poverty. The top 10 identified pathogenic strains, in sequence, were Rhizopus arrhizus (28.66\%), Rhizopus microspores (8.26\%), Lichtheimia corymbifera (5.94\%), Cunninghamella bertholletiae (3.53\%), Apophysomyces elegans (3.06\%), Apophysomyces variabilis (2.6\%), Rhizopus homothallicus (2.41\%), Saksenaea vasiformis (2.32\%), Rhizomucor pusillus (1.76\%), Lichtheimia ramosa (1.3\%). To our surprise, Mucor racemosus, which had been recognized as one of the medically important Mucorales [20] showed no reported case in our data, as well as Jeong's result [4]. However, as Prakash has figured out, the true prevalence may be far underestimated in mucormycosis, with the difficulties in collecting specimens and diagnostic tests, especially in some high incidence Asian countries [8].

\subsection{Sequence analysis and assemblies of the whole genomes}


De novo sequencing of four pathogenic Mucorales isolates B50a, B63a, B66h and B81a (Table 2) were generated by Illumina Novaseq 6000 with PE150 mode. B81a had the longest raw reads as 4.88GB, while $\mathrm{B} 66 \mathrm{~h}$ had the shortest one as 13.7GB. B50a (8.11GB raw reads) and B63a (11.68GB raw reads) were intermediate in the sequence reads. Correspondingly, B50a had the minimum PacBio reads as 931,044,277 while B63a had the maximum ones as 1,546,237,919. In between, B66h had 1,167,129,942 and B81a had 1,403,589,167 PacBio reads. All four genomes had similar Q30 value of clean reads (92.73-93.97\%). For following genome assembly and analysis, we have chosen the entire subreads longer than 500bp. B81a had the largest genome of the four isolates $(51.80 \mathrm{Mb})$, while B66h had the smallest one (32.29Mb). B50a (33.99Mb) and B63a (38.99Mb) owned the moderate genome sizes. The overall $\mathrm{G}+\mathrm{C}$ content of the four isolates entire genome were $37.86 \%$ in $\mathrm{B} 50 \mathrm{a}, 43.44 \%$ in $\mathrm{B} 63 \mathrm{a}, 33.05 \%$ in B66h and 35.71\% in B81a. We predicted 8,458 genes in B50a, 11,099 genes in B63a, 5,013 genes in B66h and 11,109 genes in B81a, which covered a total of 12,932,300 bp of the genome with a mean length of $1,529 \mathrm{bp}$ per gene, total of $16,636,830 \mathrm{bp}$ of the genome with $1499 \mathrm{bp}$ per gene, total of $6,975,655 \mathrm{bp}$ of the genome with 1392 per gene, and total of $13,553,219 \mathrm{bp}$ of the genome with 1,220 per gene, respectively. Moreover, we identified 37 rRNA genes and 242 tRNA genes in B50a, 257 rRNA genes and 254 tRNA genes in B63a, 149 rRNA genes and 300 tRNA genes in B66h, and 40rRNA genes and 299 tRNA genes in B81a.

The whole genome sequencing of four Mucorales isolates have been uploaded to NCBI respectively: SRR16108680: Mucor irregularis (B50a), SRR16108679: Lichtheimia corymbifera (B63a), SRR16108678: Mucor hiemalis (B66h) and SRR16108677: Rhizopus arrhizus (B81a). 
Table 2

De novo sequencing results of four pathogenic Mucorales isolates B50a, B63a, B66h and B81a.

\begin{tabular}{|lllll|}
\hline & $\begin{array}{l}\text { Mucor } \\
\text { irregularis }\end{array}$ & $\begin{array}{l}\text { Lichtheimia } \\
\text { corymbifera }\end{array}$ & $\begin{array}{l}\text { Mucor } \\
\text { hiemalis }\end{array}$ & $\begin{array}{l}\text { Rhizopus } \\
\text { arrhizus }\end{array}$ \\
\hline Genome Size: & $33,988,018$ & $38,994,095$ & $32,290,736$ & $51,800,396$ \\
\hline GC Content(\%): & 37.87 & 43.45 & 33.05 & 35.7 \\
\hline Gene Number: & 8,457 & 11,099 & 5,013 & 11,109 \\
\hline Gene Total Length: & $12,930,096$ & $16,636,830$ & $6,975,655$ & $13,553,220$ \\
\hline Gene Average Length: & 1,529 & 1,499 & 1,392 & 1,220 \\
\hline $\begin{array}{l}\text { Gene's GC Content: } \\
\text { \% of Genome (Genes): }\end{array}$ & 42.25 & 46.04 & 38.21 & 39.2 \\
\hline $\begin{array}{l}\text { Intergenic region } \\
\text { Length: }\end{array}$ & $21,057,922$ & $22,357,265$ & 21.6 & 26.16 \\
\hline $\begin{array}{l}\text { Intergenic's GC } \\
\text { Content: }\end{array}$ & 35.18 & 41.52 & $25,315,081$ & $38,247,176$ \\
\hline $\begin{array}{l}\text { \% of Genome } \\
\text { Intergenic): }\end{array}$ & 61.96 & 57.34 & 31.63 & 34.46 \\
\hline
\end{tabular}

\subsection{Repetitive sequences and genome annotation}

Repetitive sequences (RS) have been shown to serve as vehicle to maintain genomic variability and to serve evolutionary change. We identified a total of $6,488 \mathrm{RSs}$ in B50a occupying $2.12 \%$ of the global genome, 13,337 RSs in B63a with 3.44\%, 6,214 RSs in B66h with 1.98\%, and 20,845 RSs in B81a with $20.90 \%$.

The gene sequences of B50a, B63a, B66h and B81a were compared against NR, GO, SWISS-Prot, KEGG and EGGNOG databases. The prediction of gene function from NR revealed 7692 genes which accounted for $90.95 \%$ of entire genome in $\mathrm{B} 50 \mathrm{a}, 10938$ genes in $\mathrm{B} 60 \mathrm{a}$ with a percentage of $98.55 \%, 4800$ genes in B66h with a percentage of $95.75 \%$ and 10689 genes in B81a took a percentage of $96.22 \%$.

With NR protein database, the prediction of gene function from the clusters of orthogroups (KOG) database were 5541 genes in B50a, 6970 genes in B63a, 3847 genes in B66h and 7137 genes in B81a (data not shown).

\subsection{Pan-genome and phylogenetic analysis}

According to the pathogenic proportions of mucormycosis, we assembled, annotated and analyzed the genomes of (i) 25 species of the Mucorales order, including Rhizopus (Rhizopus arrhizus, Rhizopus microsporus, Rhizopus stolonifer, Rhizopus delemar), Mucor (Mucor circinelloides, Mucor hiemalis, Mucor indicus, Mucor irregularis, Mucor lusitanicus, Mucor racemosus and Mucor velutinosus), Lichtheimia 
(Lichtheimia corymbifera, Lichtheimia ramosa), Apophysomyces (Apophysomyces elegans, Apophysomyces ossiformis, Apophysomyces trapeziformis, Apophysomyces variabilis), Rhizomucor (Rhizomucor miehei, Rhizomucor pusillus), Cunninghamella (Cunninghamella bertholletiae, Cunninghamella elegans), Syncephalastrum (Syncephalastrum monosporum, Syncephalastrum racemosum), Actinomucor (Actinomucor elegans) and Cokeromyces (Cokeromyces recurvatus), and (ii) 22 isolates of the non-Mucorales genera, including Conidiobolus (Conidiobolus incongruous and Conidiobolus coronatus), Basidiobolus (Basidiobolus heterosporus and Basidiobolus meristosporus), Dermatophyte (Trichophyton rubrum, Trichophyton violaceum, Trichophyton mentagrophytes and Microsporum canis), Candida (Candida albicans, Candida glabrata, Candida parapsilosis, Candida tropicalis, Candida orthopsilosis and Candida metapsilosis), Cryptococcus (Cryptococcus neoformans and Cryptococcus gattii), Malassezia (Malassezia furfur, Malassezia dermatis and Malassezia globosa), and Aspergillus (Aspergillus niger, Aspergillus flavus and Aspergillus fumigatus) to identify both of common and taxa-specific genetic elements in Mucorales and pathogenic non-Mucorales fungi (Table S2).

Pan-genome analysis was conducted to figure out Mucorales-specific genes, as well as in different Mucorales species to find out Mucorales genus-specific genes. One comparison of all 47 fungal genomes indicated that Mucorales species have 50 specific orthogroups which appear discrepant expression levels (Figure 3). Mucorales-specific orthogroups showed distinct homology to Non-Redundant (NR) Protein Sequence Database (Table 3). In sequence, OG0003655 had 96.9\% similarity with EPB92269.1 as the STE/STE20 protein kinase, OG0002531 had 83\% similarity with GAN03371.1 as TRM2 tRNA methyltransferase 2 homolog A, OG0000774 had $81.2 \%$ similarity with GAN00621.1 as pkinase-domaincontaining protein, OG0004491 had $78.3 \%$ similarity with GAN01313.1 as transmembrane and coiled-coil domain-containing protein 3 , and OG0002100 had 76.7\% similarity with OAD09236.1 as glycoside hydrolase family 36 protein. Another comparison in the 9 Mucorales genera, genomes shared 1157 common orthogroups (Figure 4). Cunninghamella spp. owned the most specific orthogroups with 741 ones, followed by Lichtheimia spp. (333 orthogroups). Instead, Rhizopus spp. had 22 specific orthogroups and Mucor spp. had none. Based on the KOG database, the putative proteins were functionally classified into 22 molecular families covering cellular structure, biochemistry metabolism, molecular processing, and signal transduction (Figure 5). Orthogroups functioned more as signal transduction mechanisms in Apophysomyces spp. at 22.34\% (42/188). The common orthogroups of Cunninghamella spp. gathered more in posttranslational modification, protein turnover, chaperones at $14.18 \%$ (37/261), as well as that of Lichtheimia spp. at 26.80\% (26/97). Intracellular trafficking, secretion, and vesicular transport appeared to be main function in the common orthogroups of Syncephalastrum species. 
Table 3

Information of the Mucorales-specific orthogroups compared to NR database.

\begin{tabular}{|llll|}
\hline Orthogroup & $\begin{array}{l}\text { NR tophit } \\
\text { name }\end{array}$ & NR tophit description & $\begin{array}{l}\text { NR top } \\
\text { Similarity }\end{array}$ \\
\hline OG0003655 & EPB92269.1 & $\begin{array}{l}\text { STE/STE20 protein kinase [Mucor circinelloides } f . \\
\text { circinelloides 1006PhL] }\end{array}$ & $96.9 \%$ \\
\hline OG0002531 & GAN03371.1 & $\begin{array}{l}\text { TRM2 tRNA methyltransferase 2 homolog A [Mucor } \\
\text { ambiguus] }\end{array}$ & $83 \%$ \\
\hline OG0000774 & GAN00621.1 & pkinase-domain-containing protein [Mucor ambiguus] & $81.2 \%$ \\
\hline OG0004491 & GAN01313.1 & $\begin{array}{l}\text { transmembrane and coiled-coil domain-containing } \\
\text { protein 3 [Mucor ambiguus] }\end{array}$ & $78.3 \%$ \\
\hline OG0001006 & GAN03654.1 & $\begin{array}{l}\text { glycoside hydrolase family 36 protein [Mucor } \\
\text { circinelloides f. lusitanicus CBS 277.49] }\end{array}$ & $76.7 \%$ \\
\hline OG0003562 & PHZ17618.1 & $\begin{array}{l}\text { Quino protein alcohol dehydrogenase-like protein } \\
\text { [Rhizopus microsporus ATCC 52813] }\end{array}$ & $67.5 \%$ \\
\hline OG0002562 & GAN07947.1 & small GTPase rabE [Mucor ambiguus] & $58.6 \%$ \\
\hline OG0002218 & OBZ90755.1 & Centrosomal protein [Choanephora cucurbitarum] & $51.1 \%$ \\
\hline OG0002849 & OBZ88254.1 & $\begin{array}{l}\text { DNA-dependent protein kinase catalytic subunit } \\
\text { [Choanephora cucurbitarum] }\end{array}$ & $51 \%$ \\
\hline
\end{tabular}

Based on the pan-genome analysis data, a maximum likelihood-based phylogenetic tree was constructed in 25 Mucorales fungi and 18 non-Mucorales fungi, with 4 Entomopthorales fungi as outgroups (Figure 6). We confirmed that Mucorales species were far away from non-Mucorales species. In addition, we noticed that the $M$. irregularis (B50a) and $M$. hiemalis (B66h) were clustered in one clade, sharing a very close relationship. Cokeromyces recurvatus and Actinomucor elegans were phylogenetically related to Mucorspp. within one phylogenetic cluster.

\subsection{Expressions of proteins related to the virulence}

To verify the reported proteins related to the virulence of Mucorales species, the copies of these proteins were compared in Mucorales species and other pathogenic fungi. Despite that arf and aqp1 showed no difference, atf, gcn4, igp 1, pps1, mcmyo5, mcplD, 112092, hmgR, cotH3 and fob had significant difference while ico1 varied slightly between the two groups (Figure 7). For further knowledge of the unequal pathogenicity of the Mucorales species, we listed the expression of proteins related to the virulence in all the fungi we have referred above (Figure 8). Few expressions of $112092, \operatorname{cotH} 3, g c n 4$ and igp 1 was detected in non-Mucorales species, while almost all the Mucorales species expressed in different levels. Although the protein expression of $f o b$ and $h m g R$ exhibited significant difference between Mucorales species and other pathogenic fungi, both were not as high as other proteins. 
Compared to the non-Mucorales species, Mucorales species displayed abundant but uneven expression levels of pps1, atf, mcplD and mcmyo5. Gene pps1 expressed mainly in Rhizopus stolonifer, Rhizopus delemar and Mucor irregularis, atf had high expression in Mucor racemosus, Rhizopus delemar, Mucor Iusitanicus, Mucor circinelloides and Rhizopus arrhizus, mcp/D expressed more in Rhizopus stolonifer, Apophysomyces elegans and Mucor racemosus; mcmyo5 had multiple expressions in Rhizopus stolonifer, Mucor racemosus and Rhizopus delemar.

\section{Discussion}

Mucormycosis often causes high morbidity and mortality for its rapidly processive and destructive nature, of which urgent surgical and medical intervention can be lifesaving [21] [22] [23] [24]. Successful management depends on early diagnosis and optimal intervention. The availability of imaging techniques, trained and experienced physician, and mycological and histological investigations are extremely important in diagnosing mucormycosis. In the global guideline for the diagnosis and management of mucormycosis published in 2019, molecular-based methods for direct detection are moderately supported for the lack of standardization [25]. Several attempts have been done to detect Mucorales DNA in tissue samples [26-30], blood [31-33] and other fluids [34-37] as a non-invasive method of early diagnosis or pre-emptive therapy. PCR amplification of various DNA targets (ITS, 18S, $28 \mathrm{~S}$, cytochrome B) have been evaluated but lacking standardization for clinical application. Our study aimed to discover more potential DNA targets to enhance the possibility of molecular-based methods for rapid and accurate detection.

Based on the pan-genomic comparison of Mucorales species and non-Mucorales pathogenic fungi species, we have exhibited a few Mucorales-specific genes. EPB92269.1, encoding STE/STE20 protein kinase, seems to be a fundamental role in mitogen-activated protein kinase (MAPK) pathway, regulating cell wall maintenance, filamentous growth, and virulence [38]. Series of STE20 homologs have been suggested as a critical virulence factor for Candida albicans as CST20 [39] and CaCla4p [40], and Trichophyton rubrum as the p21 activated kinase (PAK) [41]. OAD09236.1 encodes glycoside hydrolase family 36 protein (GH36), which usually contains bacterial a-galactosidases. Up to now, a few fungal agalactosidases that belong to $\mathrm{GH} 36$ have been reported, such as those from Lichtheimia ramosa (LrAga/36A) [42], Rhizomucor miehei (RmGa/36) [43] and Gibberella sp. F75 (aga-F75) [44]. Different GH36 a-galactosidases show distinct activities under acidic conditions and physiological temperatures [44]. GAN03654.1 has high similarity with sel1 repeat protein, which has been suggested as the virulence determinant in Legionella pneumophila (IpnE), influencing vacuolar trafficking [45].

Seen from our frequency outcomes, the causative pathogens of mucormycosis with high incidence are Rhizopus species, Mucor species and Lichtheimia species. Although only sparse evidence supports that identification of the causative Mucorales to the genus or species level, or both, could guide the choice of the antifungal treatment [46-48], identification down to the species level is of importance for improved epidemiological knowledge in some outbreaks[49, 50]. However, identification of the Mucorales species in culture by standard mycological methods such as morphology is notoriously difficult because different 
species share similar morphological characteristics (Figure 9). Some reference laboratories pointed out a high level of concordance ( $>90 \%$ ) between morphology and molecular identification [51]. Also, some novel Mucorales PCR assays $[52,53]$ are released but likely to be designed to detect the order Mucorales as a whole, or individual genera, while Mucorales genus-specific gene targets still remain to be discussed.

In our pan-genome comparisons of Mucorales species, 22 specific orthogroups were detected but described only as hypothetical proteins for Rhizopus species which need to be further studied (data not shown). Beyond our expectation, none of the orthogroups was specific for Mucor species. Seven isolates had been included and compared in Mucor species, much more than other species, which might account for this unexpected outcome. When comparing the amino acid sequences specific in Lichtheimia species, several homologs show high similarity to identified proteins in posttranslational modification, protein turnover, chaperones, lipid transport and metabolism, including AMP-dependent synthetase ligase; fatty acid ligase; vacuolar transporter chaperone 4; a chain RMP-pepstatin A complex; DnaJ homolog subfamily A member 4; aspartic protease; cysteine proteinase; calmodulin; ubiquitin carboxyl-terminal hydrolase 12-like protein; multidrug resistance (MDR)-associated protein and MFS multidrug transporter (Table 4). 
Table 4

Lichtheimia species-specific homologs.

\begin{tabular}{|c|c|c|c|}
\hline Orthogroup & $\begin{array}{l}\text { NR tophit } \\
\text { name }\end{array}$ & NR tophit description & $\begin{array}{l}\text { NR top } \\
\text { Similarity }\end{array}$ \\
\hline OG0020222 & CDH52151.1 & $\begin{array}{l}\text { achain rmp-pepstatin a complex [Lichtheimia } \\
\text { corymbifera JMRC:FSU:9682] }\end{array}$ & 100 \\
\hline OG0020221 & CDH52152.1 & $\begin{array}{l}\text { achain x-ray analyses of aspartic structure } \\
\text { andrefinement at angstroms resolution of the } \\
\text { asparticproteinase from mucor pusillus [Lichtheimia } \\
\text { corymbifera JMRC:FSU:9682] }\end{array}$ & 100 \\
\hline OG0011126 & CDH58664.1 & $\begin{array}{l}\text { achain } x \text {-ray analyses of aspartic structure } \\
\text { andrefinement at angstroms resolution of the } \\
\text { asparticproteinase from mucor pusillus [Lichtheimia } \\
\text { corymbifera JMRC:FSU:9682] }\end{array}$ & 99.5 \\
\hline OG0011105 & CDH50014.1 & $\begin{array}{l}\text { amp binding protein [Lichtheimia corymbifera } \\
\text { JMRC:FSU:9682] }\end{array}$ & 98.4 \\
\hline OG0020099 & CDH50004.1 & $\begin{array}{l}\text { amp-dependent synthetase ligase [Lichtheimia } \\
\text { corymbifera JMRC:FSU:9682] }\end{array}$ & 100 \\
\hline OG0020129 & CDH48850.1 & $\begin{array}{l}\text { aspartic protease [Lichtheimia corymbifera } \\
\text { JMRC:FSU:9682] }\end{array}$ & 100 \\
\hline OG0020281 & CDH59824.1 & calmodulin [Lichtheimia corymbifera JMRC:FSU:9682] & 96 \\
\hline OG0020241 & CDH56523.1 & $\begin{array}{l}\text { cysteine proteinase [Lichtheimia corymbifera } \\
\text { JMRC:FSU:9682] }\end{array}$ & 97.2 \\
\hline OG0020248 & CDH58463.1 & $\begin{array}{l}\text { dnaj homolog subfamily a member } 4 \text { [Lichtheimia } \\
\text { corymbifera JMRC:FSU:9682] }\end{array}$ & 100 \\
\hline OG0015056 & $\mathrm{CDH} 49832.1$ & $\begin{array}{l}\text { fatty-acid--ligase [Lichtheimia corymbifera } \\
\text { JMRC:FSU:9682] }\end{array}$ & 95.6 \\
\hline OG0020268 & $\mathrm{CDH} 49831.1$ & $\begin{array}{l}\text { long-chain-fatty-acid-ligase [Lichtheimia corymbifera } \\
\text { JMRC:FSU:9682] }\end{array}$ & 100 \\
\hline OG0020236 & CDH57209.1 & $\begin{array}{l}\text { major facilitator superfamily protein [Lichtheimia } \\
\text { corymbifera JMRC:FSU:9682] }\end{array}$ & 82.5 \\
\hline OG0020075 & CDH57125.1 & mef2c protein [Lichtheimia corymbifera JMRC:FSU:9682] & 89.9 \\
\hline OG0020042 & CDH50594.1 & $\begin{array}{l}\text { mfs multidrug transporter [Lichtheimia corymbifera } \\
\text { JMRC:FSU:9682] }\end{array}$ & 89.3 \\
\hline
\end{tabular}

Additionally, Cunninghamella genera have been associated with an increased mortality rate in patients [46, 47] and shown to be more virulent in experimental models[48], with several homologs shown high similarity in Posttranslational modification, protein turnover, chaperones and transcription. Such as vanillate O-demethylase; secretory lipase, glutathione S-transferase; alpha/beta hydrolase fold family; ferric reductase, NADH/NADPH oxidase; amino acid permease/ SLC12A domain-containing protein; thiolase; C6 transcription factor; DCG1-like protein; exo-beta-1; pantothenate transporter; cathepsin L-like; FAD binding domain protein and so on (Table 5). 


\begin{tabular}{|llll|}
\hline Orthogroup & $\begin{array}{l}\text { NR tophit } \\
\text { name }\end{array}$ & NR tophit description & $\begin{array}{c}\text { NR top } \\
\text { Similarity }\end{array}$ \\
\hline OG0020122 & CDH49091.1 & $\begin{array}{l}\text { multidrug resistance-associated protein 1-like } \\
\text { [Lichtheimia corymbifera JMRC:FSU:9682] }\end{array}$ & 98.3 \\
\hline OG0020150 & CDH60432.1 & $\begin{array}{l}\text { ubiquitin carboxyl-terminal hydrolase 12-like [Lichtheimia } \\
\text { corymbifera JMRC:FSU:9682] }\end{array}$ & 93.4 \\
\hline OG0020186 & CDH60762.1 & vtc4p [Lichtheimia corymbifera JMRC:FSU:9682] & 100 \\
\hline $\begin{array}{l}\text { Additionally, Cunninghamella genera have been associated with an increased mortality rate in } \\
\text { patients [46, 47] and shown to be more virulent in experimental models[48], with several homologs } \\
\text { shown high similarity in Posttranslational modification, protein turnover, chaperones and } \\
\text { transcription. Such as vanillate O-demethylase; secretory lipase, glutathione S-transferase; alpha/beta } \\
\text { hydrolase fold family; ferric reductase, NADH/NADPH oxidase; amino acid permease/ SLC12A } \\
\text { domain-containing protein; thiolase; C6 transcription factor; DCG1-like protein; exo-beta-1; } \\
\text { pantothenate transporter; cathepsin L-like; FAD binding domain protein and so on (Table 5). }\end{array}$ \\
\hline
\end{tabular}


Table 5

Cunninghamella species-specific homologs.

\begin{tabular}{|c|c|c|c|}
\hline Orthogroup & $\begin{array}{l}\text { NR tophit } \\
\text { name }\end{array}$ & NR tophit description & $\begin{array}{l}\text { NR top } \\
\text { Similarity }\end{array}$ \\
\hline OG0013781 & RMZ47002.1 & alpha/beta fold family hydrolase [Aspergillus flavus] & 100 \\
\hline OG0001523 & KAB8248670.1 & $\begin{array}{l}\text { amino acid permease/ SLC12A domain-containing } \\
\text { protein [Aspergillus flavus] }\end{array}$ & 99.6 \\
\hline OG0019965 & OAQ35848.1 & arsenate reductase [Mortierella elongata AG-77] & 62.8 \\
\hline OG0010164 & RMZ48341.1 & Asp-hemolysin precursor [Aspergillus flavus] & 100 \\
\hline OG0004525 & EED49147.1 & $\begin{array}{l}\text { C6 transcription factor (Leu3), putative [Aspergillus } \\
\text { flavus NRRL3357] }\end{array}$ & 86.1 \\
\hline OG0005683 & KOC11690.1 & C6 transcription factor [Aspergillus flavus AF70] & 92.8 \\
\hline OG0019923 & OQR66474.1 & cathepsin L-like [Tropilaelaps mercedesae] & 69 \\
\hline OG0006743 & CAF32059.1 & DCG1-like protein, putative [Aspergillus fumigatus] & 99 \\
\hline OG0019762 & PIA12612.1 & DNA polymerase [Coemansia reversa NRRL 1564] & 68.9 \\
\hline OG0005197 & RMZ39367.1 & exo-beta-1 [Aspergillus flavus] & 98 \\
\hline OG0007683 & PIG88081.1 & FAD binding domain protein [Aspergillus arachidicola] & 67.4 \\
\hline OG0005204 & ORX90396.1 & $\begin{array}{l}\text { FAD-binding domain-containing protein [Basidiobolus } \\
\text { meristosporus CBS 931.73] }\end{array}$ & 74.2 \\
\hline OG0000278 & KDE76689.1 & $\begin{array}{l}\text { ferric reductase, NADH/NADPH oxidase [Aspergillus } \\
\text { oryzae 100-8] }\end{array}$ & 99.9 \\
\hline OG0000667 & EED56953.1 & $\begin{array}{l}\text { glutathione S-transferase, putative [Aspergillus flavus } \\
\text { NRRL3357] }\end{array}$ & 100 \\
\hline OG0007862 & EAL86257.1 & $\begin{array}{l}\text { GNAT family N-acetyltransferase, putative } \\
\text { [Aspergillus fumigatus Af293] }\end{array}$ & 88.4 \\
\hline OG0008586 & RAQ76907.1 & O-methyltransferase [Aspergillus flavus] & 100 \\
\hline OG0006933 & 00010681.1 & $\begin{array}{l}\text { Oxidoreductase FAD-binding domain protein } \\
\text { [Aspergillus oryzae] }\end{array}$ & 92.3 \\
\hline OG0006958 & RMZ44899.1 & pantothenate transporter [Aspergillus flavus] & 84.5 \\
\hline
\end{tabular}

According to the reported proteins related to virulence of Mucorales species, 112092, cotH3, gcn4 and igp 1 expressed few in non-Mucorales species but abundant in almost all Mucorales species. Studied from the former studys, deletion of gene 112092 results in significant reduction of Mucor circinelloides virulence [13]; cotH3 has been identified as the fungal ligands that mediate attachment to GRP78 during host cell invasion [18]; $g c n 4$ deletion causes severe germination and growth defects in the spores after phagocytosis, affecting the development of mucormycosis in mice [11]; deletion mutants in igp 1 develops healthy colonies similar to wild-type virulent strain but leads to less death of mice [11]. Thus, the four DNA targets might be designed for the direct identification as well as the virulence detection of Mucorales species. 


\begin{tabular}{|c|c|c|c|}
\hline Orthogroup & $\begin{array}{l}\text { NR tophit } \\
\text { name }\end{array}$ & NR tophit description & $\begin{array}{l}\text { NR top } \\
\text { Similarity }\end{array}$ \\
\hline OG0019721 & ORZ05233.1 & $\begin{array}{l}\text { phosphoesterase family-domain-containing protein } \\
\text { [Absidia repens] }\end{array}$ & 74.3 \\
\hline OG0001102 & RMZ37442.1 & secretory lipase [Aspergillus flavus] & 100 \\
\hline OG0006483 & KJK61788.1 & $\begin{array}{l}\text { specific transcription factor domain protein } \\
\text { [Aspergillus parasiticus SU-1] }\end{array}$ & 93.5 \\
\hline OG0006748 & RDH19797.1 & $\begin{array}{l}\text { squalene-hopene-cyclase [Aspergillus niger ATCC } \\
\text { 13496] }\end{array}$ & 100 \\
\hline OG0019940 & ORZ18196.1 & $\begin{array}{l}\text { Thiolase, N-terminal domain-domain-containing } \\
\text { protein [Absidia repens] }\end{array}$ & 93.8 \\
\hline OG0009144 & RMZ46722.1 & $\begin{array}{l}\text { vanillate 0-demethylase oxidoreductase [Aspergillus } \\
\text { flavus] }\end{array}$ & 100 \\
\hline \multicolumn{4}{|c|}{$\begin{array}{l}\text { According to the reported proteins related to virulence of Mucorales species, } 112092, \operatorname{cotH} 3, g c n 4 \text { and } \\
\text { igp } 1 \text { expressed few in non-Mucorales species but abundant in almost all Mucorales species. Studied } \\
\text { from the former studys, deletion of gene } 112092 \text { results in significant reduction of Mucor } \\
\text { circinelloides virulence [13]; cotH3 has been identified as the fungal ligands that mediate attachment } \\
\text { to GRP78 during host cell invasion [18]; gcn4 deletion causes severe germination and growth defects } \\
\text { in the spores after phagocytosis, affecting the development of mucormycosis in mice [11]; deletion } \\
\text { mutants in igp } 1 \text { develops healthy colonies similar to wild-type virulent strain but leads to less death of } \\
\text { mice [11]. Thus, the four DNA targets might be designed for the direct identification as well as the } \\
\text { virulence detection of Mucorales species. }\end{array}$} \\
\hline
\end{tabular}

\section{Conclusions}

We completed the whole genome sequencing of three common pathogenic Mucorales species and one uncommon species from CAMS-CCPM-D to study our epidemiological results of mucormycosis. As we have mentioned above, some regions cannot identify the Mucorales to genus or species which may lead to some deviation in our epidemiological statistics.

To find out the Mucorales-specific genes or genus-specific genes in Mucorales, and to seek the possibility of direct detections in serum or other body fluids for identification to genus/species, we compared the whole genome sequencing of Mucorales species and non-Mucorales species. A few Mucorales-specific genes have been found which are related to STE/STE20 protein kinase, GH36 and sel1 repeat protein. Mucorales genus-specific genes are also discussed here, especially those of Lichtheimia species and Cunninghamella species, which covered cellular structure, biochemistry metabolism, molecular processing, and signal transduction. Reported proteins related to the virulence of Mucorales species were varied with distinct significance while $h m g R 3,112092, \operatorname{cotH} 3, g c n 4$ and igp 1 have the potential to be the detection targets.

The best informative DNA target should have a large intergenus (between genus) and a low intragenus (within a given genus) sequence variability, which brings us the dawn of new technology for rapid and 
convenient diagnosis, and accurate and efficient treatments.

\section{Declarations}

Author Contributions: Conceptualization, Zhang, M.J. and Liang, G.Z.; methodology, Zhang, M.J. Xu, W.Q. and Liang, G.Z.; software, Zhang, M.J. and Tao, Y.; validation, Zhang, M.J. and Ge, N.C.; formal analysis, Zhang, M.J. and Song, G.; investigation, Zhang, M.J. and Liang, G.Z.; resources, Zhang, M.J. and Mei H.; data curation, Zhang, M.J.; writing-original draft preparation, Zhang, M.J.; writing-review and editing, Zhang, M.J. and Liang, G.Z.; visualization, Zhang, M.J.; supervision, Liu W.D. and Liang; project administration, Liu W.D. and Liang, G.Z.; funding acquisition, Liu W.D. and Liang, G.Z. All authors have read and agreed to the published version of the manuscript.

Funding: This work was funded by the National Natural Science Foundation of China, grant number 81471905; the Nanjing Incubation Program for National Clinical Research Center, grant number 2019060001; the National Science and Technology Infrastructure of China, grant number National Pathogen Resource Center- NPRC- 32.

Institutional Review Board Statement: Not applicable.

Informed Consent Statement: Not applicable.

Data Availability Statement: The whole genome sequencing of four Mucorales isolates have been uploaded to NCBI (https://www.ncbi.nlm.nih.gov) respectively: SRR16108680: Mucor irregularis (B50a), SRR16108679: Lichtheimia corymbifera (B63a), SRR16108678: Mucor hiemalis (B66h) and SRR16108677: Rhizopus arrhizus (B81a).

Acknowledgments: We would like to thank Shanghai BIOZERON Biotechnology Co. (www.biozeron.com) for providing sequencing technologies and bioinformatic analysis. Thanks for the wonderful supporting work from Fuxing Zha, Xiaomeng Cao and Yan Cheng.

Conflicts of Interest: The authors declare no conflict of interest. The funders had no role in the design of the study; in the collection, analyses, or interpretation of data; in the writing of the manuscript, or in the decision to publish the results.

\section{References}

1. Park BJ, Pappas PG, Wannemuehler KA, Alexander BD, Anaissie EJ, Andes DR, Baddley JW, Brown $\mathrm{JM}$, Brumble LM, Freifeld AG et al: Invasive non-Aspergillus mold infections in transplant recipients, United States, 2001-2006. Emerg Infect Dis 2011, 17(10):1855-1864.

2. Chakrabarti A, Chatterjee SS, Das A, Panda N, Shivaprakash MR, Kaur A, Varma SC, Singhi S, Bhansali A, Sakhuja V: Invasive zygomycosis in India: experience in a tertiary care hospital. Postgrad Med J 2009, 85(1009):573-581. 
3. Lelievre L, Garcia-Hermoso D, Abdoul H, Hivelin M, Chouaki T, Toubas D, Mamez AC, Lantieri L, Lortholary O, Lanternier F: Posttraumatic mucormycosis: a nationwide study in France and review of the literature. Medicine (Baltimore) 2014, 93(24):395-404.

4. Jeong W, Keighley C, Wolfe R, Lee WL, Slavin MA, Kong DCM, Chen SC: The epidemiology and clinical manifestations of mucormycosis: a systematic review and meta-analysis of case reports. Clin Microbiol Infect 2019, 25(1):26-34.

5. Prakash H, Ghosh AK, Rudramurthy SM, Singh P, Xess I, Savio J, Pamidimukkala U, Jillwin J, Varma S, Das A et al: A prospective multicenter study on mucormycosis in India: Epidemiology, diagnosis, and treatment. Med Mycol 2019, 57(4):395-402.

6. Chakrabarti A, Das A, Mandal J, Shivaprakash MR, George VK, Tarai B, Rao P, Panda N, Verma SC, Sakhuja V: The rising trend of invasive zygomycosis in patients with uncontrolled diabetes mellitus. Med Mycol 2006, 44(4):335-342.

7. Lin E, Moua T, Limper AH: Pulmonary mucormycosis: clinical features and outcomes. Infection 2017, 45(4):443-448.

8. Prakash H, Chakrabarti A: Global Epidemiology of Mucormycosis. J Fungi (Basel) 2019, 5(1).

9. Singh AK, Singh R, Joshi SR, Misra A: Mucormycosis in COVID-19: A systematic review of cases reported worldwide and in India. Diabetes Metab Syndr 2021, 15(4):102146.

10. Song G, Liang G, Liu W: Fungal Co-infections Associated with Global COVID-19 Pandemic: A Clinical and Diagnostic Perspective from China. Mycopathologia 2020, 185(4):599-606.

11. Pérez-Arques C, Navarro-Mendoza MI, Murcia L, Lax C, Martínez-García P, Heitman J, Nicolás FE, Garre V: Mucor circinelloides Thrives inside the Phagosome through an Atf-Mediated Germination Pathway. mBio 2019, 10(1).

12. Trieu TA, Navarro-Mendoza MI, Pérez-Arques C, Sanchis M, Capilla J, Navarro-Rodriguez P, LopezFernandez L, Torres-Martínez S, Garre V, Ruiz-Vázquez RM et al: RNAi-Based Functional Genomics Identifies New Virulence Determinants in Mucormycosis. PLoS Pathog 2017, 13(1):e1006150.

13. López-Fernández L, Sanchis M, Navarro-Rodríguez P, Nicolás FE, Silva-Franco F, Guarro J, Garre V, Navarro-Mendoza MI, Pérez-Arques C, Capilla J: Understanding Mucor circinelloides pathogenesis by comparative genomics and phenotypical studies. Virulence 2018, 9(1):707-720.

14. Patiño-Medina JA, Maldonado-Herrera G, Pérez-Arques C, Alejandre-Castañeda V, Reyes-Mares NY, Valle-Maldonado MI, Campos-García J, Ortiz-Alvarado R, Jácome-Galarza IE, Ramírez-Díaz MI et al: Control of morphology and virulence by ADP-ribosylation factors (Arf) in Mucor circinelloides. Curr Genet 2018, 64(4):853-869.

15. Patiño-Medina JA, Valle-Maldonado MI, Maldonado-Herrera G, Pérez-Arques C, Jácome-Galarza IE, Díaz-Pérez C, Díaz-Pérez AL, Araiza-Cervantes CA, Villagomez-Castro JC, Campos-García J et al: Role of Arf-like proteins (Arl1 and Arl2) of Mucor circinelloides in virulence and antifungal susceptibility. Fungal Genet Biol 2019, 129:40-51.

16. Nagy G, Vaz AG, Szebenyi C, Takó M, Tóth EJ, Csernetics Á, Bencsik O, Szekeres A, Homa M, Ayaydin $F$ et al: CRISPR-Cas9-mediated disruption of the HMG-CoA reductase genes of Mucor circinelloides 
and subcellular localization of the encoded enzymes. Fungal Genet Biol 2019, 129:30-39.

17. Bellanger AP, Tatara AM, Shirazi F, Gebremariam T, Albert ND, Lewis RE, Ibrahim AS, Kontoyiannis DP: Statin Concentrations Below the Minimum Inhibitory Concentration Attenuate the Virulence of Rhizopus oryzae. J Infect Dis 2016, 214(1):114-121.

18. Gebremariam T, Liu M, Luo G, Bruno V, Phan QT, Waring AJ, Edwards JE, Jr., Filler SG, Yeaman MR, Ibrahim AS: CotH3 mediates fungal invasion of host cells during mucormycosis. J Clin Invest 2014, 124(1):237-250.

19. Liu M, Lin L, Gebremariam T, Luo G, Skory CD, French SW, Chou TF, Edwards JE, Jr., Ibrahim AS: Fob1 and Fob2 Proteins Are Virulence Determinants of Rhizopus oryzae via Facilitating Iron Uptake from Ferrioxamine. PLoS Pathog 2015, 11(5):e1004842.

20. Singh P, Paul S, Shivaprakash MR, Chakrabarti A, Ghosh AK: Stress response in medically important Mucorales. Mycoses 2016, 59(10):628-635.

21. Chamilos G, Lewis RE, Kontoyiannis DP: Delaying amphotericin B-based frontline therapy significantly increases mortality among patients with hematologic malignancy who have zygomycosis. Clin Infect Dis 2008, 47(4):503-509.

22. Vaughan $\mathrm{C}$, Bartolo A, Vallabh N, Leong SC: A meta-analysis of survival factors in rhino-orbitalcerebral mucormycosis-has anything changed in the past 20 years? Clin Otolaryngol 2018, 43(6):1454-1464.

23. Sun HY, Singh N: Mucormycosis: its contemporary face and management strategies. Lancet Infect Dis 2011, 11(4):301-311.

24. Liang GZ, Xu WQ, Zheng XL, Mei H, Lv GX, Shen YN, Li DM, Liu WD: Successful Treatment by Surgery of a Primary Cutaneous Mucormycosis Caused by Mucor irregularis. Mycopathologia 2018, 183(2):445-449.

25. Cornely OA, Alastruey-Izquierdo A, Arenz D, Chen SCA, Dannaoui E, Hochhegger B, Hoenigl M, Jensen $\mathrm{HE}$, Lagrou K, Lewis RE et al: Global guideline for the diagnosis and management of mucormycosis: an initiative of the European Confederation of Medical Mycology in cooperation with the Mycoses Study Group Education and Research Consortium. Lancet Infect Dis 2019, 19(12):e405-e421.

26. Guinea J, Escribano P, Vena A, Muñoz P, Martínez-Jiménez MDC, Padilla B, Bouza E: Increasing incidence of mucormycosis in a large Spanish hospital from 2007 to 2015: Epidemiology and microbiological characterization of the isolates. PLoS One 2017, 12(6):e0179136.

27. Rickerts V, Mousset S, Lambrecht E, Tintelnot K, Schwerdtfeger R, Presterl E, Jacobi V, Just-Nübling G, Bialek R: Comparison of histopathological analysis, culture, and polymerase chain reaction assays to detect invasive mold infections from biopsy specimens. Clin Infect Dis 2007, 44(8):1078-1083.

28. Alanio A, Garcia-Hermoso D, Mercier-Delarue S, Lanternier F, Gits-Muselli M, Menotti J, Denis B, Bergeron A, Legrand M, Lortholary $\mathrm{O}$ et al: Molecular identification of Mucorales in human tissues: contribution of PCR electrospray-ionization mass spectrometry. Clin Microbiol Infect 2015, 21(6):594.e591-595. 
29. Dannaoui E, Schwarz P, Slany M, Loeffler J, Jorde AT, Cuenca-Estrella M, Hauser PM, Shrief R, Huerre $M$, Freiberger $T$ et al: Molecular detection and identification of zygomycetes species from paraffinembedded tissues in a murine model of disseminated zygomycosis: a collaborative European Society of Clinical Microbiology and Infectious Diseases (ESCMID) Fungal Infection Study Group (EFISG) evaluation. J Clin Microbiol 2010, 48(6):2043-2046.

30. Gholinejad-Ghadi N, Shokohi T, Seifi Z, Aghili SR, Roilides E, Nikkhah M, Pormosa R, Karami H, Larjani LV, Ghasemi $\mathrm{M}$ et al: Identification of Mucorales in patients with proven invasive mucormycosis by polymerase chain reaction in tissue samples. Mycoses 2018, 61(12):909-915.

31. Kasai M, Harrington SM, Francesconi A, Petraitis V, Petraitiene R, Beveridge MG, Knudsen T, Milanovich J, Cotton MP, Hughes $\mathrm{J}$ et al: Detection of a molecular biomarker for zygomycetes by quantitative PCR assays of plasma, bronchoalveolar lavage, and lung tissue in a rabbit model of experimental pulmonary zygomycosis. J Clin Microbiol 2008, 46(11):3690-3702.

32. Legrand M, Gits-Muselli M, Boutin L, Garcia-Hermoso D, Maurel V, Soussi S, Benyamina M, Ferry A, Chaussard M, Hamane S et al: Detection of Circulating Mucorales DNA in Critically III Burn Patients: Preliminary Report of a Screening Strategy for Early Diagnosis and Treatment. Clin Infect Dis 2016, 63(10):1312-1317.

33. Kobayashi M, Togitani K, Machida H, Uemura Y, Ohtsuki Y, Taguchi H: Molecular polymerase chain reaction diagnosis of pulmonary mucormycosis caused by Cunninghamella bertholletiae. Respirology 2004, 9(3):397-401.

34. Shigemura T, Nakazawa Y, Matsuda K, Motobayashi M, Saito S, Koike K: Evaluation of Mucorales DNA load in cerebrospinal fluid in a patient with possible cerebral mucormycosis treated with intravenous liposomal amphotericin B. Int J Infect Dis 2014, 29:200-202.

35. Lengerova M, Racil Z, Hrncirova K, Kocmanova I, Volfova P, Ricna D, Bejdak P, Moulis M, Pavlovsky Z, Weinbergerova $B$ et al: Rapid detection and identification of mucormycetes in bronchoalveolar lavage samples from immunocompromised patients with pulmonary infiltrates by use of highresolution melt analysis. J Clin Microbiol 2014, 52(8):2824-2828.

36. Scherer E, Iriart X, Bellanger AP, Dupont D, Guitard J, Gabriel F, Cassaing S, Charpentier E, Guenounou S, Cornet M et al: Quantitative PCR (qPCR) Detection of Mucorales DNA in Bronchoalveolar Lavage Fluid To Diagnose Pulmonary Mucormycosis. J Clin Microbio/2018, 56(8).

37. Springer J, White PL, Kessel J, Wieters I, Teschner D, Korczynski D, Liebregts T, Cornely OA, Schwartz S, Elgeti T et al: A Comparison of Aspergillus and Mucorales PCR Testing of Different Bronchoalveolar Lavage Fluid Fractions from Patients with Suspected Invasive Pulmonary Fungal Disease. J Clin Microbiol 2018, 56(2).

38. Boyce KJ, Andrianopoulos A: Ste20-related kinases: effectors of signaling and morphogenesis in fungi. Trends Microbio/ 2011, 19(8):400-410.

39. Leberer E, Harcus D, Broadbent ID, Clark KL, Dignard D, Ziegelbauer K, Schmidt A, Gow NA, Brown AJ, Thomas DY: Signal transduction through homologs of the Ste20p and Ste7p protein kinases can 
trigger hyphal formation in the pathogenic fungus Candida albicans. Proc Natl Acad Sci U S A 1996, 93(23):13217-13222.

40. Leberer E, Ziegelbauer K, Schmidt A, Harcus D, Dignard D, Ash J, Johnson L, Thomas DY: Virulence and hyphal formation of Candida albicans require the Ste20p-like protein kinase CaCla4p. Curr Biol 1997, 7(8):539-546.

41. Gomes EV, Bortolossi JC, Sanches PR, Mendes NS, Martinez-Rossi NM, Rossi A: STE20/PAKA Protein Kinase Gene Releases an Autoinhibitory Domain through Pre-mRNA Alternative Splicing in the Dermatophyte Trichophyton rubrum. Int J Mol Sci 2018, 19(11).

42. Xie J, Wang B, He Z, Pan L: A thermophilic fungal GH36 a-galactosidase from Lichtheimia ramosa and its synergistic hydrolysis of locust bean gum. Carbohydr Res 2020, 491:107911.

43. Katrolia P, Jia H, Yan Q, Song S, Jiang Z, Xu H: Characterization of a protease-resistant agalactosidase from the thermophilic fungus Rhizomucor miehei and its application in removal of raffinose family oligosaccharides. Bioresour Technol 2012, 110:578-586.

44. Cao Y, Wang Y, Meng K, Bai Y, Shi P, Luo H, Yang P, Zhou Z, Zhang Z, Yao B: A novel protease-resistant alpha-galactosidase with high hydrolytic activity from Gibberella sp. F75: gene cloning, expression, and enzymatic characterization. App/ Microbiol Biotechnol 2009, 83(5):875-884.

45. Newton HJ, Sansom FM, Dao J, McAlister AD, Sloan J, Cianciotto NP, Hartland EL: Sel1 repeat protein LpnE is a Legionella pneumophila virulence determinant that influences vacuolar trafficking. Infect Immun 2007, 75(12):5575-5585.

46. Roden MM, Zaoutis TE, Buchanan WL, Knudsen TA, Sarkisova TA, Schaufele RL, Sein M, Sein T, Chiou CC, Chu JH et al: Epidemiology and outcome of zygomycosis: a review of 929 reported cases. Clin Infect Dis 2005, 41(5):634-653.

47. Gomes MZ, Lewis RE, Kontoyiannis DP: Mucormycosis caused by unusual mucormycetes, nonRhizopus, -Mucor, and -Lichtheimia species. Clin Microbiol Rev 2011, 24(2):411-445.

48. Petraitis V, Petraitiene R, Antachopoulos C, Hughes JE, Cotton MP, Kasai M, Harrington S, Gamaletsou MN, Bacher JD, Kontoyiannis DP et al: Increased virulence of Cunninghamella bertholletiae in experimental pulmonary mucormycosis: correlation with circulating molecular biomarkers, sporangiospore germination and hyphal metabolism. Med Mycol 2013, 51(1):72-82.

49. Etienne KA, Gillece J, Hilsabeck R, Schupp JM, Colman R, Lockhart SR, Gade L, Thompson EH, Sutton DA, Neblett-Fanfair $R$ et al: Whole genome sequence typing to investigate the Apophysomyces outbreak following a tornado in Joplin, Missouri, 2011. PLoS One 2012, 7(11):e49989.

50. Garcia-Hermoso D, Criscuolo A, Lee SC, Legrand M, Chaouat M, Denis B, Lafaurie M, Rouveau M, Soler C, Schaal JV et al: Outbreak of Invasive Wound Mucormycosis in a Burn Unit Due to Multiple Strains of Mucor circinelloides f. circinelloides Resolved by Whole-Genome Sequencing. mBio 2018, 9(2).

51. Alvarez E, Sutton DA, Cano J, Fothergill AW, Stchigel A, Rinaldi MG, Guarro J: Spectrum of zygomycete species identified in clinically significant specimens in the United States. $J$ Clin Microbiol 2009, 47(6):1650-1656. 
52. Guegan H, Iriart X, Bougnoux ME, Berry A, Robert-Gangneux F, Gangneux JP: Evaluation of MucorGenius ${ }^{\circledR}$ mucorales PCR assay for the diagnosis of pulmonary mucormycosis. J Infect 2020, 81(2):311-317.

53. Rocchi S, Scherer E, Mengoli C, Alanio A, Botterel F, Bougnoux ME, Bretagne S, Cogliati M, Cornu M, Dalle $F$ et al: Interlaboratory evaluation of Mucorales PCR assays for testing serum specimens: A study by the fungal PCR Initiative and the Modimucor study group. Med Mycol 2021, 59(2):126-138.

\section{Figures}

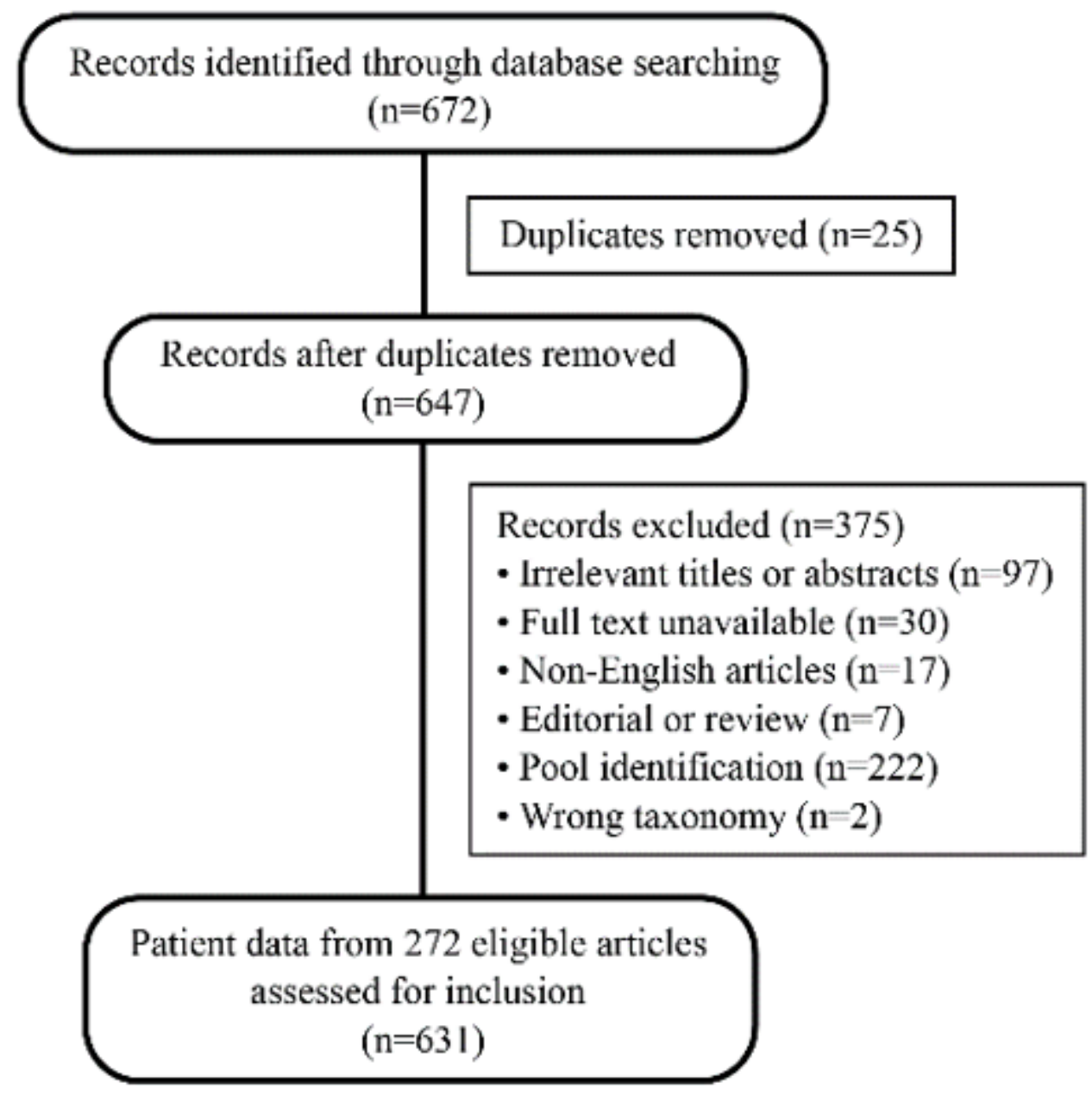

Figure 1

Searching flowchart for causative pathogens. There were 672 records received initially, of which removed the duplications $(n=25)$ and records with exclusions $(n=375)$. All in all, 631 new patient data from 272 eligible articles were included in our analysis.

Figure 2 
Causative pathogens condition of murcomycosis: (A) Proportions of different Mucorales genus, and (B) Proportions of different Mucorales species shown in the column diagram while the top 10 species individually pictured in pie charts.

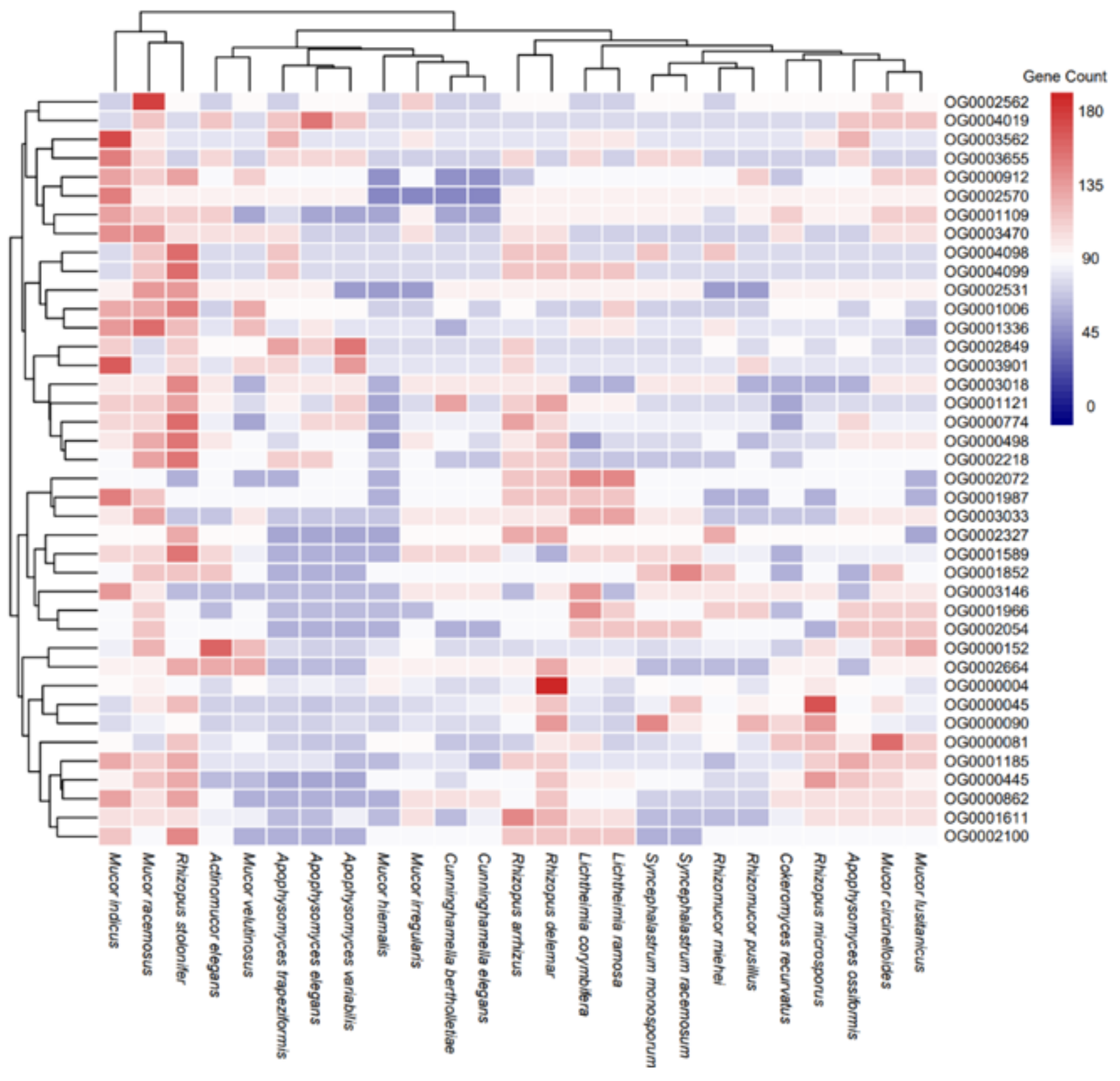

Figure 3

There were 50 Mucorales genus-specific orthogroups appearing discrepant expression levels in different Mucorales species. 


\section{Cokeromyces spp.}

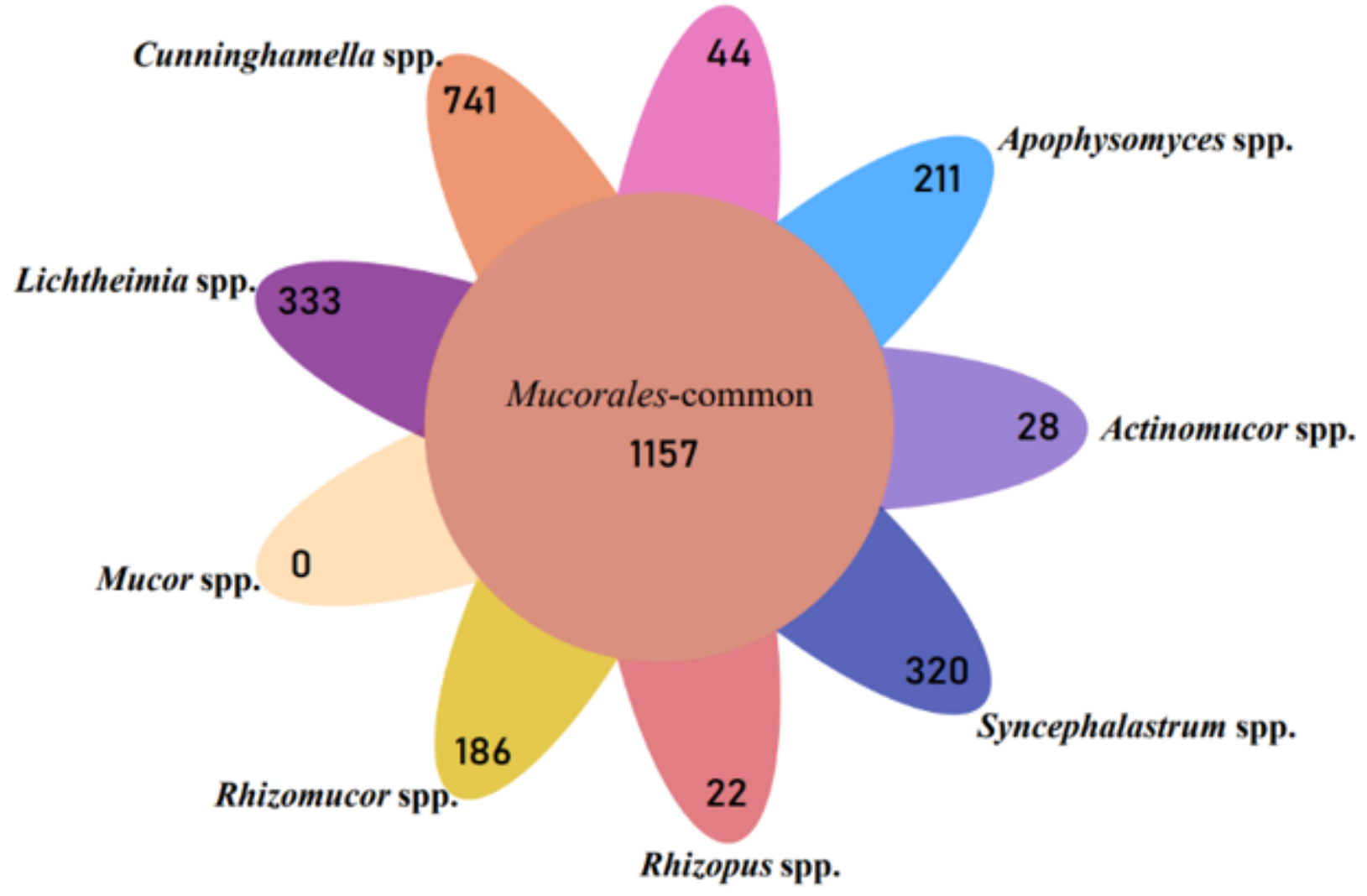

\section{Figure 4}

Pan-genome comparison in the 9 Mucorales genera. All genomes shared 1157 common orthogroups and distinct specific orthogroups for each Mucorales genus except Mucor species.

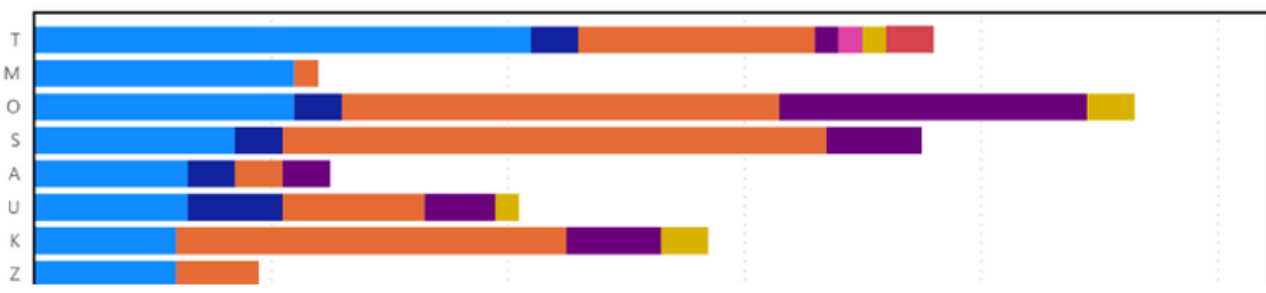

A: RNA processing and modification

B : Chromatin structure and dynamics

C : Energy production and conversion

D : Cell cycle control, cell division, chromosome partitioning

E : Amino acid transport and metabolism

F : Nucleotide transport and metabolism

G : Carbohydrate transport and metabolism 
Figure 5

Histogram of KOG classification of the 9 Mucorales genera. All unigenes were aligned to KOG database for prediction and classification based on available and possible functions.

\section{Figure 6}

Core pan analysis and evolutionary tree. Genera of Mucorales have been marked in different colors.

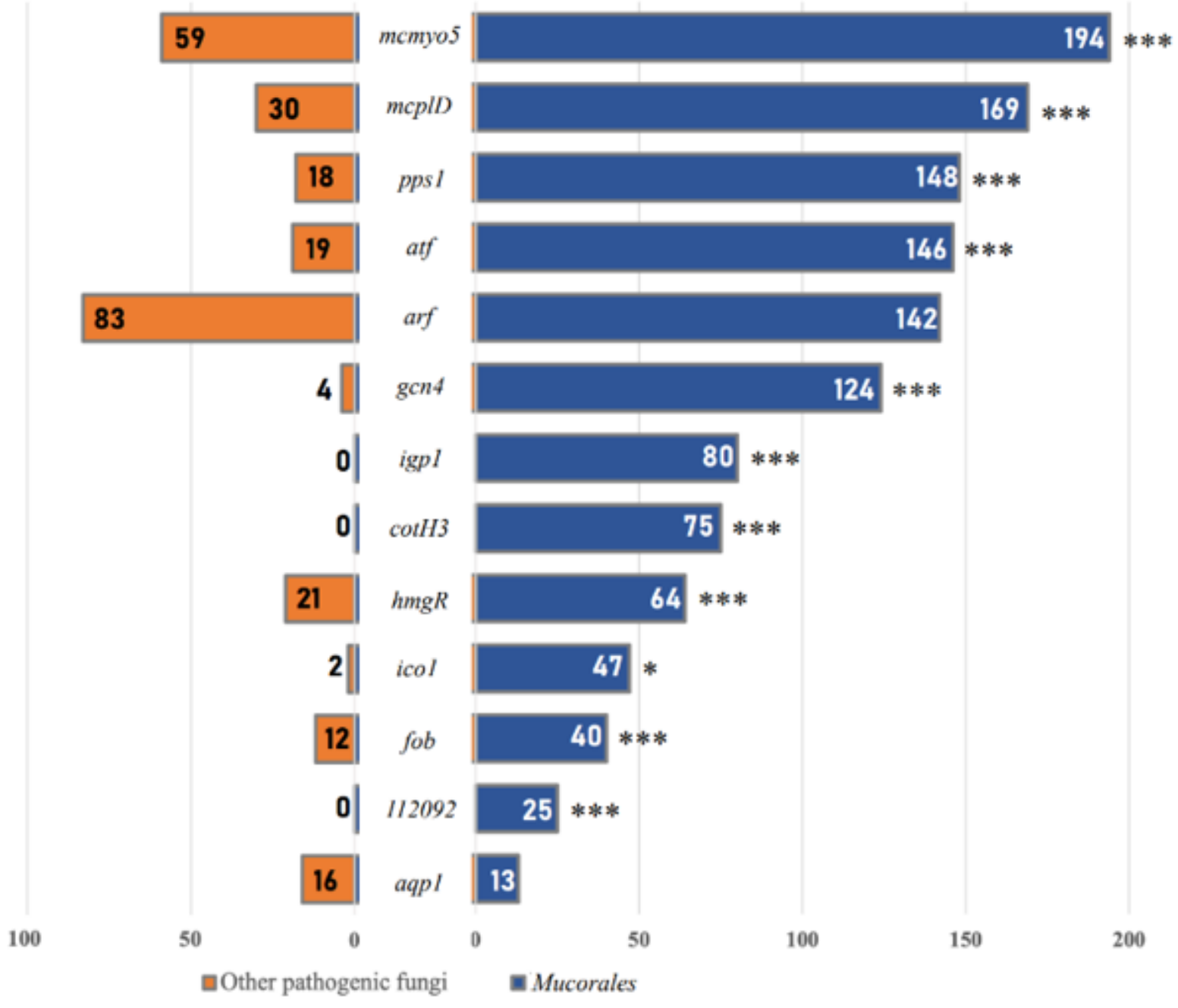

Figure 7

Comparison of virulence related proteins between Mucorales species and other pathogenic fungi. (*: $<0.05 ; * \star *:<0.001)$ 


\begin{tabular}{|c|c|c|c|c|c|c|c|c|c|c|c|c|c|c|}
\hline & 1 & 0 & 0 & 1 & 0 & 3 & 0 & 0 & 2 & 1 & 11 & 4 & 2 & Apophysomyces elegans \\
\hline & 1 & 0 & 0 & 1 & 1 & 2 & 0 & 0 & 2 & 1 & 7 & 4 & 0 & Apophysomyces trapeziform/s \\
\hline & 1 & 0 & 0 & 1 & 1 & 3 & 0 & 0 & 2 & 1 & 7 & 4 & 2 & Apophysomyces varlabills \\
\hline & 1 & 0 & 1 & 1 & 0 & 1 & 0 & 2 & 2 & 4 & 1 & 8 & 2 & Basidiobolus heterosporus \\
\hline & 0 & 0 & 0 & 0 & 0 & 2 & 0 & 0 & 2 & 4 & 4 & 4 & 0 & Conidlobolus Incongruus \\
\hline & 0 & 1 & 0 & 0 & 0 & 1 & 0 & 4 & 0 & 1 & 2 & 4 & 6 & Cryptococcus gattll \\
\hline & 0 & 1 & 0 & 0 & 0 & 1 & 0 & 2 & 0 & 1 & 2 & 4 & 6 & Cryptococcus neoformans \\
\hline & 0 & 0 & 0 & 0 & 0 & 1 & 0 & 4 & 0 & 0 & 1 & 3 & 5 & Malassezla dermatis \\
\hline & 0 & 0 & 0 & 0 & 0 & 1 & 0 & 6 & 0 & 1 & 1 & 3 & 4 & Malassezia furfur \\
\hline & 0 & 2 & 1 & 0 & 0 & 2 & 0 & 0 & 0 & 3 & 3 & 2 & 4 & Aspergillus flavus \\
\hline
\end{tabular}

Figure 8

Expression heatmap of proteins related to the virulence in all the 47 fungi. Mucorales species were in the black frames. 

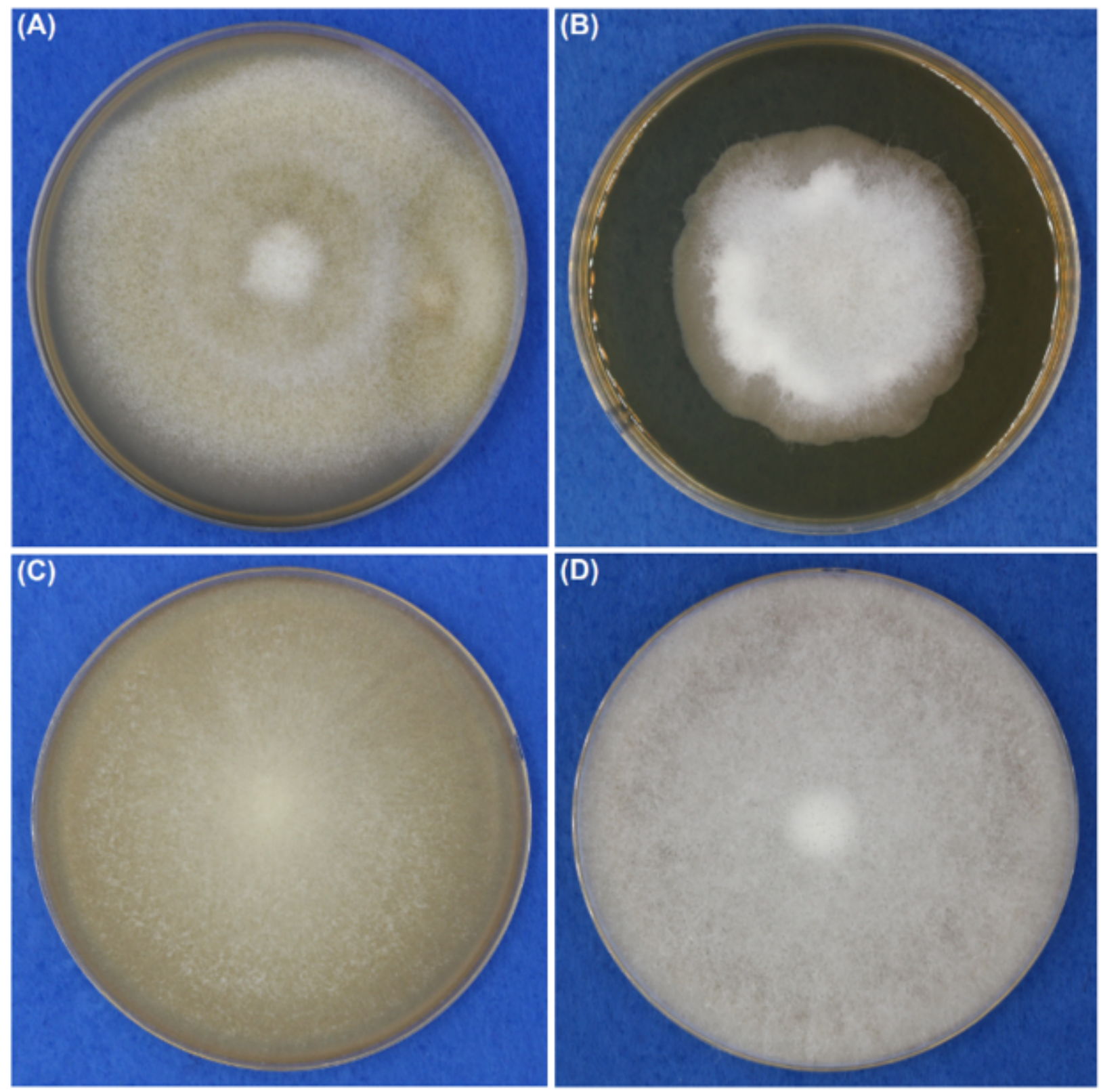

\section{Figure 9}

Morphology of four Mucorales isolates on MEA media after a 4-day culture at $30^{\circ} \mathrm{C}$. (A) Mucor irregularis (CMFCCC B50a), (B) Lichtheimia corymbifera (CMFCCC B63a), (C) Mucor hiemalis (CMFCCC B66h) and (D) Rhizopus arrhizus (CMFCCC B81a).

\section{Supplementary Files}

This is a list of supplementary files associated with this preprint. Click to download.

- TableS1.xlsx

- TableS2.xlsx

- supplementarymaterial.docx 